\title{
Dampak Pengembangan Ekowisata Hutan Magrove terhadap Sosial dan Ekonomi Masyarakat di Desa Kuala Langsa, Aceh
}

\author{
The Impact of Mangrove Forest Ecotourism Development \\ on Communities' Social and Economic in Kuala Langsa Village, Aceh
}

\author{
Safuridar $^{1)}$, Puti Andiny ${ }^{2)}$ \\ ${ }^{1,2)}$ Fakultas Ekonomi, Universitas Samudra, Kota Langsa \\ e-mail korespondensi: safuridar@unsam.ac.id
}

\begin{tabular}{|l|}
\hline Info Artikel \\
\hline Riwayat Artikel : \\
Diterima: 26 November 2019 \\
Disetujui: 18 Desember 2019 \\
Dipublikasikan: Januari 2020 \\
\hline Nomor DOI \\
10.33059/jseb.v11i1.1882 \\
Cara Mensitasi : \\
Safuridar \& Andiny, P. 2020. \\
Dampak Pengembangan \\
Ekowisata Hutan Mangrove \\
terhadap Sosial dan Ekonomi \\
Masyarakat di Desa Kuala \\
Langsa, Aceh. Jurnal \\
Samudra Ekonomi dan \\
Bisnis. 11(1): 43-52.
\end{tabular}

Bisnis. 11(1): 43-52.

\begin{abstract}
Abstrak
Tujuan dari penelitian ini adalah untuk mengetahui dampak sosial dan ekonomi terhadap pengembangan Ekowisata Hutan Mangrove di Kota Langsa. Metode analisis yang digunakan dalam penelitian ini adalah analisis identifikasi dampak pengembangan hutan magrove terhadap social dan ekonomi masyarakat di Kota Langsa. Sampel dalam penelitian ini berjumlah 100 orang yang merupakan masyarakat yeng terkena dampak di sekitar hutan mangrove. Berdasarkan hasil penelitian, dengan adanya pengembangan ekowisata hutan mangrove dapat menambah kegiatan masyarakat. Dampak-dampak lainnya adalah membuka lapangan kerja baru, meningkatkan pendapatan, meningkatkan kesejahteraan, menyediakan fasilitas umum, meningkatkan PAD, dan lain-lain. Sedangkan dampak yang paling rendah dalam pengembangan hutan mangrove adalah terjadinya konflik sosial dalam masyarakat. Keberadaan hutan mangrove sangat menunjang tingkat perkembangan sosial dan perekonomian masyarakat di sekitarnya. Dari segi ekonomis, hutan mangrove merupakan sumber penghasilan produk hasil hutan yang bernilai ekonomis tinggi.
\end{abstract}

Kata Kunci: Dampak Sosial-Ekonomi, Eksternalitas, Ekowisata, Hutan Mangrove.

\begin{tabular}{|l|}
\hline Article Info \\
\hline Article History : \\
Received: 26 November 2019 \\
Accepted: 18 December 2019 \\
Published: January 2020 \\
\hline DOI Number : \\
10.33059/jseb.v11i1.1882 \\
How to cite : \\
Safuridar \& Andiny, P. 2020. \\
Dampak Pengembangan \\
Ekowisata Hutan Mangrove \\
terhadap Sosial dan Ekonomi \\
Masyarakat di Desa Kuala \\
Langsa, Aceh. Jurnal \\
Samudra Ekonomi dan \\
Bisnis. 11(1): 43-52.
\end{tabular}

Abstract

The study aims to determine the social and economic impact on the development of Mangrove Forest Ecotourism in Langsa City. The analytical method used in this research is to identify the impact of mangrove forest development on the social and economic community in Langsa City. The sample amounted to 100 people who are affected by the community around the mangrove forest. Based on results, the development of mangrove forest ecotourism can increase community activities. Other impacts are opening new jobs, increasing income, increasing welfare, providing public facilities, increasing PAD, and others. While the lowest impact in the development of mangrove forests is the occurrence of social conflict in the community. The existence of mangrove forests greatly supports the level of social and economic development of the surrounding community. From an economic perspective, mangrove forests are a source of income from forest products that are of high economic value.

Keywords: Socio-Economic Impact, Externality, Ecotourism, Mangrove Forest. 


\section{PENDAHULUAN}

Pariwisata berperan penting dalam pembangunan ekonomi di berbagai negara, sehingga membuat pariwisata disebut sebagai passport to development, new kind sugar, tool for regional development, invisible eksport, non polluting industry (Pitana \& Putu, 2005). Dengan adanya kegiatan pariwisata diharapkan dapat membantu perekonomian dalam suatu daerah. Pengembangan ekowisata juga seharusnya memperhatikan keadaan lingkungan agar ekowisata yang ada di suatu daerah bisa berkelanjutan di masa yang akan datang. Menurut organisasi The Ecotorism Society, ekowisata merupakan bentuk perjalanan wisata ke daerah alami yang dilakukan dengan tujuan konservasi lingkungan, melestarikan dan mensejahterakan kehidupan masyarakat setempat (Wibowo, 2007). Oleh karena itu sepatutnya ekowisata layak untuk dikeloloa dan dikembangkan, agar keberlangsungan ekowisata akan tetap berlangsung dan tetap ada di masa yang akan datang. Salah satu ekowiasata yang patut dikembangkan dan dikelola adalah hutan mangrove. Hal ini karena hutan mangrove pada saat ini mulai terancam kualitasnya, sehingga dibutuhkan penanganan dan pengelolaan yang baik dan bijaksana.

Keberadaan hutan mangrove sangat menentukan dan menunjang tingkat perkembangan sosial dan perekonomian masyarakat disekitarnya. Dari segi ekonomis, hutan mangrove merupakan sumber penghasil produk hasil hutan yang bernilai ekonomis tinggi, seperti kayu, sumber pangan, bahan kosmetika, bahan pewarna dan penyamak kulit, serta sumber pakan ternak dan lebah. Selain itu, hutan mangrove merupakan tempat tinggal berbagai jenis ikan dan udang serta hewan-hewan lainnya. Hal itu diharapkan dapat mendukung peningkatan perekonomian masyarakat yang berada di area sekitar hutan manggrove. Pada beberapa tipe ekologi wilayah pantai, hutan mangrove sangat berperan penting bagi perlindungan wilayah dari abrasi pantai, pencegah intrusi air laut, serta sebagai penyangga terhadap sedimentasi dari daratan ke lautan.

Misi Kota Langsa adalah melanjutkan penataan kota untuk menciptakan lingkungan yang hijau, sehat, indah, nyaman, tertib dan aman serta meningkatkan taraf kesejahteraan ekonomi masyarakat melalui penataan ekowisata mangrove serta pembangunan masyarakat sadar wisata. Berdasarkan misi tersebut, maka dibutuhkan pembangunan yang berkelanjutan dengan memadukan kemampuan lingkungan, sumber daya alam serta teknologi sebagai upaya untuk melestarikan lingkungan hutan mangrove di Kota Langsa. Kota Langsa sendiri merupakan satu-satunya Kota di Aceh yang berhasil mengembangkan sektor pariwisata ekosistem mangrove yang terletak di Kuala Langsa Kecamatan Langsa Barat Kota Langsa dengan luas sebesar 8.000 Ha (Badan Pusat Statistik, 2018).

Desa Kuala Langsa yang terletak di pesisir pantai Kecamatan Langsa Barat Kota Langsa, dengan luas ekosistem hutan mangrove sebesar 8.000 Ha. Oleh karena itu, banyak pihak yang terlibat langsung dalam pemanfaatan ekowisata hutan mangrove diantaranya petambak, nelayan pencari ikan, pencari kepiting, pencari udang, pencari kerang, pencari kayu bakar, penyedia kuliner, pedagang kecil dan lain-lain. Pengelolaan dan perencanaan diperlukan untuk mendukung kelancaran dalam pengembangan hutan mangrove di Kota Langsa. Pemerintah dan masyarakat harus bekerjasama dalam mengembangkan ekowisata hutan mangrove.

Kegiatan ekowisata adalah alternatif yang sangat efektif untuk menanggulangi permasalahan lingkungan seperti tingkat eksploitasi kayu mangrove yang berlebihan oleh masyarakat yang ada di Kuala Langsa. 
Agar kegiatan pengelolaan dan pemanfaatan ekowisata hutan mangrove di Kuala Langsa dapat berlangsung secara berkelanjutan dan optimal maka pengembangan hutan mangrove perlu disesuaikan dengan potensi sumber daya yang ada.

Ekosistem mangrove merupakan suatu ekosistem pantai yang unik dan menarik dan banyak memberikan kontribusi atau manfaat terhadap kehidupan masyarakat, baik manfaat secara langsung maupun manfaat tidak langsung yang mempunyai nilai ekonomi tinggi. Hutan mangrove memiliki nilai estetika, baik dari faktor alamnya maupun dari kehidupan yang ada di dalamnya. Hutan mangrove memberikan objek wisata yang berbeda dengan objek wisata alam lainnya. Karakteristik hutannya yang berada di peralihan antara darat dan laut memiliki keunikan dan pesona alam yang sangat indah sehingga bisa dijadikan sebagai objek wisata alam oleh masyarakat. Hal ini dapat mendorong masyarakat baik secara domestik maupun masyarakat luar domstik untuk melakukan wisata ke hutan mangrove.

Berdasarkan data dari Badan Pusat Statistik tahun 2018, jumlah wisatawan yang datang berkunjung ke tempat wisata yang ada di Kota Langsa adalah sebanyak 742.089 orang atau meningkat sebesar 10,24 persen dari tahun sebelumnya. Hal ini membuktikan bahwa pada saat ini Kota Langsa sudah menjadi salah satu tujuan destinasi pariwisata bagi wisatawan dalam negeri maupun mancanegara. Trend jumlah kunjungan wisatawan di Kota Langsa pada tahun 2018 dapat dilihat dalam Tabel 1.

Tabel 1. Jumlah Kunjungan Wisatawan Nusantara dan Mancanegara ke Objek Wisata di Kota Langsa pada Tahun 2018

\begin{tabular}{clc}
\hline No & Nama Objek & Jumlah Pengunjung (orang) \\
\hline 1 & Hutan Mangrove Kuala Langsa & 156.031 \\
2 & Hutan Kota Langsa & 405.189 \\
3 & Mutiara Water Park & 53.228 \\
4 & Taman Bambu Runcing & 17.566 \\
5 & Vitra Tirta Raya Swimming Pool & 42.027 \\
6 & Pusat Jajanan Kuliner & 48.125 \\
7. & Royal Water Boom & 19.923 \\
\hline & Jumlah
\end{tabular}

Sumber: Dinas Pemuda, Olah Raga dan Pariwisata Kota Langsa, 2019.

Kota Langsa memiliki objek wisata yang bisa dikunjungi oleh wisatawan diantaranya Hutan Mangrove, Hutan Kota Langsa, Mutia Water Park, Taman Bambu Runcing, Virta Tirta Swimming Pool, Pusat Jajanan Kuliner Kota Langsa dan Royal Water Boom. Berdasarkan Tabel 1 dapat dilihat bahwa jumlah wisatawan tertinggi yang berkunjung ke objek wisata di Kota Langsa adalah kunjungan ke Hutan Kota
Langsa dan Hutan Mangrove. Data Ini membuktikan bahwa dua objek wisata ini merupakan tempat favorit bagi wisatawan, terutama hutan mangrove dimana hutan ini masih sangat alami dengan lingkungan yang sangat asri.

Dengan berkembangnya ekowisata mangrove diharapkan mampu memberikan dampak atau pengaruh yang positif berupa berkembangnya perekonomian daerah, yang 
selanjutnya akan berpengaruh positif terhadap terbukanya kesempatan kerja yang semakin luas dan meningkatnya pendapatan perkapita masyarakat.

Namun demikian, berkembangnya situs ekowisata mangrove juga memberikan pengaruh negatif terhadap keamanan dan lingkungan berupa kerusakan lingkungan, pencemaran udara maupun pencemaran lingkungan. Begitu pula dengan adanya pengembangan hutan mangrove juga memberikan pengaruh secara fisik bagi hutan itu sendiri dan juga pengaruh sosial dan ekonomi bagi masyarakat di sekitar hutan mangrove, serta juga untuk kemajuan perekonomian Kota Langsa.

Menurut Soemarwoto (dalam Andiny \& Irwan, 2009), seorang pakar lingkungan, setiap kegiatan akan bisa mengakibatkan dampak terhadap lingkungan, demikian pula kegiatan manusia dalam aktivitas pembangunan juga akan dapat menimbulkan dampak terhadap lingkungan, baik dampak yang bersifat positif maupun negatif. Hal ini akan dapat mempengaruhi keberlangsungan ekowisata hutan mangrove di Kota Langsa.

Dahuri et al. (2001) menjelaskan bahwa keberadaan kelompok swadaya masyarakat dan lembaga swadaya masyarakat sangat diperlukan dalam pengelolaan wilayah pesisir secara terpadu. Kegiatan wisata di area hutan mangrove Kuala Langsa memberikan hasil pendapatan langsung bagi pengelola melalui penjualan tiket masuk dan parkir. Kegiatan ini juga mampu menumbuhkan perekonomian masyarakat di sekitarnya dengan menyediakan lapangan kerja dan kesempatan berusaha, seperti membuka warung makan, dan menjadi pemandu wisata.

Disamping itu, kegiatan ini juga mampu menumbuhkan perekonomian masyarakat sekitar dengan menyediakan sejumlah lapangan pekerjaan dan kesempatan usaha disekitar area ekosistem hutan dan ekosistem pantai, juga mampu menjaga keseimbangan lingkungan dan ekosistem hutan, khususnya hutan mangrove. Para wisatawan juga memperoleh pelajaran tentang lingkungan langsung dari alam.

Berdasarkan sejumlah pemikiran yang telah diuraikan, maka tujuan dari penelitian ini adalah untuk menganalisis dampak sosial dan ekonomi terhadap pengembangan Ekowisata Hutan Mangrove di Desa Kuala Langsa.

\section{Ekowisata}

Definisi ekowisata pertama diperkenalkan oleh Ecotourism Society (Fandeli \& Mukhlison, 2000) sebagai bentuk perjalanan wisata ke area alami yang dilakukan dengan tujuan mengonservasi lingkungan dan melestarikan kehidupan serta kesejahteraan penduduk setempat. Selanjutnya, Kete (2016) mendefinisikan ekowisata sebagai suatu bentuk perjalanan wisata ke lokasi yang masih alami dengan tetap mendukung upaya konservasi dan berbasis masyarakat lokal demi terciptanya pembangunan berkelanjutan.

Menurut Damanik dan Weber (2006), ekowisata merupakan salah satu bentuk kegiatan wisata khusus yang seringkali diposisikan sebagai lawan dari wisata massal. Sebenarnya, yang membedakan dari wisata massal adalah karakteristik produk dan pasar dari kegiatan tersebut. Berbeda dengan wisata konvensional, ekowisata merupakan kegiatan wisata yang menaruh perhatian besar terhadap kelestarian sumber daya pariwisata. Masyarakat ekowisata internasional mengartikannya sebagai perjalanan wisata alam yang bertanggung jawab dengan cara mengkonservasi lingkungan dan meningkatkan kesejahteraan masyarakat lokal (The International Ecotourism Society (TIES), 2000).

Ekowisata merupakan wisata alternatif dianggap yang dianggap sebagai salah satu cara untuk meningkatkan kehidupan ekonomi 
masyarakat pedesaan karena dianggap bisa memberikan kesempatan kerja, kesempatan berusaha, serta meningkatkan perkembangan kemampuan berusaha (Scheyvens, 2000).

Ekowisata merupakan upaya konservasi yang dikemas dalam bentuk lokasi wisata sehingga pengunjung tidak hanya menikmati keindahan ekosistem alami namun juga ikut serta dalam pelestarian lingkungan. Berdasarkan panduan dasar pelaksanaan ekowisata UNESCO, terdapat lima elemen penting yang perlu diketahui oleh setiap pelaku wisata sehingga dapat menjamin pelestarian lingkungan dan peningkatan kesejahteraan masyarakat lokal (Kete, 2016). Pertama, ekowisata memberikan pengalaman dan pendidikan kepada wisatawan yang dapat meningkatkan pemahaman dan apresiasi terhadap daerah tujuan wisata yang dikunjunginya. Kedua, ekowisata memperkecil dampak negatif yang dinilai bisa merusak karakteristik lingkungan dan kebudayaan pada daerah yang dikunjungi. Ketiga, kegiatan ekowisata mengikutsertakan masyarakat dalam pengelolaan dan pelaksanaannya. Keempat, kegiatan ekowisata memberikan keuntungan ekonomi terutama kepada pihak masyarakat lokal, sehingga pelaksanaan kegiatan ekowisata harus bersifat profit (menguntungkan). Kelima, ekowisata dapat terus bertahan dan berkelanjutan.

Menurut Undang-Undang No. 26 Tahun 2007 tentang penataan ruang, status peruntukan hutan mangrove menurut fugsi utamanya yaitu Kawasan Lindung. Namun di kawasan hutan mangrove tersebut masih sering ditemui kegitan masyarakat yang cenderung merusak dengan menebangnya untuk kegiatan pengambilan untuk kayu bakar dan keperluan laiinya. Masyarakat yang bermukim di area hutan mangrove ini otomatis akan memberikan dampak yang kurang baik wilayah daerah setempat karena mengakibatkan sejumlah dampak potensial.
Kasus dampak aktivitas pabrik karet berpengaruh pada lingkungan fisik dan kimia sebagai salah satu contoh. Lingkungan fisik dapat diartikan sebagai segala sesuatu di sekitar kita yang bersifat benda mati (Andiny \& Irwan, 2009). Dampak fisik mencakup dampak kegiatan manusia yang mana secara langsung maupun tidak langsung mempengaruhi komponen fisik lingkungan atau komponen non-hayati, termasuk komponen abiotik atau komponen biogeofisik kimia yang membentuk ekosistem lingkungan. Dampak fisik dapat terlihat pada perubahan kualitas, antara lain pada sumber daya air (hidrologi), sumber daya lahan/tanah (fisiografi), sumber daya hutan, kawasan pemukiman, daya dukung lingkungan dan keindahan alam, serta warisan alam dan warisan budaya. Pelongsoran tanah, pembabatan hutan, adanya limbah beracun pada periran, kebisingan pada pemukiman (Kasmir \& Jakfar, 2012).

\section{Sosial Ekonomi}

Sosial ekonomi menurut Abdulsyani (1994) adalah kedudukan ataupun posisi seseorang dalam kelompok manusia yang ditentukan oleh jenis aktivitas ekonomi, pendapatan, tingkat pendidikan, jenis rumah tinggal, dan jabatan dalam organisasi.

Sedangkan menurut Soekanto (2001), sosial ekonomi adalah posisi seseorang dalam masyarakat berkaitan dengan orang lain dalam arti lingkungan pergaulan, prestasinya, dan hak-hak serta kewajibannya dalam hubungannya dengan sumber-sumber daya.

Berdasarkan beberapa pendapat itu, dapat disimpulkan pengertian keadaan sosial ekonomi dalam penelitian ini adalah kedudukan atau posisi seseorang dalam masyarakat berkaitan dengan tingkat pendidikan, tingkat pendapatan pemilikan kekayaan atau fasilitas serta jenis tempat tinggal. 
Dampak dari suatu kegiatan pembangunan pada aspek sosial ekonomi khususnya untuk negara berkembang meliputi beberapa komponen yang ditetapkan sebagai indikator sosial ekonomi. Komponen-komponen itu antara lain: (1) penyerapan tenaga kerja; (2) berkembangnya struktur ekonomi, yaitu timbulnya aktifitas perekonomian lain akibat proyek itu seperti toko, warung, restoran, transportasi dan lain-lain; (3) peningkatan pendapatan masyarakat; (4) kesehatan masyarakat; (5) persepsi masyarakat; dan (6) laju pertambahan penduduk, dan lain sebagainya.

Tekanan terhadap kawasan mangrove secara umum di sebabkan oleh faktor sosial ekonomi, faktor alam dan faktor kebijakan. Faktor yang dominan sebagai faktor penyebab tekanan terhadap kawasan mangrove terus berlanjut. Mata pencaharian tangkap ikan lepas pantai merupakan pekerjaan utama yang dilakukan masyarakat pesisir (nelayan) atau masyarakat tempatan (masyarakat tempatan adalah penduduk yang tinggal di pantai dan sekitarnya, baik yang merupakan pendatang maupun penduduk asli).

Menurut Suparmoko (2014), sosial ekonomi masyarakat pesisir berhubungan erat dengan sumber daya alam pesisir dan menjadi "sawah-ladang" abadi bagi masyarakat pesisir itu sendiri. Sumber daya alam yang masih baik kondisinya karena tetap dilestarikan penduduk, akan menyediakan kebutuhan penduduk itu sendiri. Sebaliknya SDA yang rusak kondisinya, karena tidak dijaga dan tidak dipelihara masyarakat sekitar, akan menyediakan kebutuhan yang sedikit bagi masyarakat.

\section{METODE PENELITIAN}

Rancangan penelitian yang digunakan dalam penelitian ini adalah deskriptif kualitatif yang bersifat menggambarkan, memaparkan dan menguraikan objek yang diteliti (Arikunto, 2006). Dengan mengguna- kan analisis deskriptif dibantu oleh program komputer, akan dapat ditampilkan deskripsi statistik berupa nilai rata-rata (mean), simpangan baku (standard deviation), dan frekuensi jawaban untuk setiap variabel. Analisis ini digunakan untuk mengetahui atau mengukur dampak sosial dan ekonomi terhadap pengembangan ekowisata hutan mangrove di Desa Kuala Langsa.

Penelitian dilakukan di Desa Kuala Langsa, Kecamatan Langsa Barat Kota Langsa. Dengan pertimbangan bahwa daerah ini adalah merupakan desa yang terkena dampak dari pengembangan ekowisata hutan mangrove di Kota Langsa dan juga merupakan desa yang terdapat berbagai jenis hutan mangrove dalam kawasan hutan lindung. Subjek dalam penelitian ini adalah masyarakat yang tinggal di sekitar hutan mangrove. Untuk memperoleh informasi maka dilakukan wawancara secara langsung tentang pengembangan hutan mangrove di Desa Kuala Langsa.

Populasi dalam penelitian ini adalah seluruh penduduk yang berada disekitar ekosistem mangrove baik yang terlibat secara langsung maupun yang tidak terkait dengan pengembangan hutan mangrove yang berjumlah 543 kepala keluaga.

Metode pengambilan sampel atau responden adalah purposive sampling, yaitu pengambilan sampel tidak secara acak melainkan berdasarkan pertimbangan jenis pemanfaatannya. Metode ini digunakan untuk menilai dampak langsung dan dampak tidak langsung dari ekowisata hutan mangrove. Untuk menentukan besar sampel minimal yang dapat mewakili keseluruhan populasi dalam penelitian ini digunakan rumus Slovin yang dikutip dari Riduwan (2009), yaitu sebagai berikut:

$$
n=\frac{N}{1+N\left(d^{2}\right)}
$$


dimana $n$ adalah besarnya sampel, $N$ adalah besarnya populasi, serta $d$ adalah tingkat kepercayaan atau ketepatan yang diinginkan. Berdasarkan rumus tersebut diperoleh sampel sebanyak:

$$
\begin{aligned}
& n=\frac{543}{1+543\left(0.01^{2}\right)} \\
& n=99,8=100 \text { orang }
\end{aligned}
$$

Berdasarkan hasil perhitungan maka diperoleh jumlah sampel sebanyak 100 responden. Pengumpulan data di lakukan dengan cara wawancara melalui kuisioner terhadap seluruh masyarakat sekitar hutan mangrove di Desa Kuala Langsa.

Sumber data dalam penelitian ini diperoleh berdasarkan data yang diperoleh dilapangan baik menggunakan data primer maupun data sekunder. Metode analisis yang digunakan adalah analisis deskriptif kualitatif yaitu melakukan penyesuain antara teori dan realita yang ada di lapangan sehingga tersusun menjadi sebuah hasil dalam proses penelitian.

\section{HASIL ANALISIS}

Desa Kuala Langsa merupakan wilayah perairan Kota Langsa yang berada di koordinat 04\%31'25" LU dan 98¹0'9" BT dengan luas wilayah $\pm 1.600 \mathrm{Ha}$. Tinggi ratarata \pm 10 mdpl. Batas-batas Desa Kuala Langsa, sebelah utara berbatasan dengan Desa Telaga Tujuh, sebelah selatan berbatasan dengan Desa Sungai Pauh, sebelah barat berbatasan dengan Desa Lhok Banie sebelah timur dengan Langsa Lama.

Mayoritas mata pencaharian penduduknya adalah nelayan, sedangkan minoritasnya bermata pencaharian di bidang jasa dan perdagangan. Sarana kesehatan yang ada di Desa Kuala Langsa berjumlah 1 puskesmas, 1 Posyandu 1 Pustu. Sarana jalan Desa Kuala Langsa sudah beraspal dan dapat dilalui kendaraan roda dua maupun roda empat dengan di sebelah kanan kiri jalan area tambak dan pemukiman penduduk. Selain itu juga Desa Kuala Langsa merupakan daerah yang yang dikelilingi oleh hutan mangrove.

Hutan mangrove Kuala Langsa secara administratif masuk dalam wilayah Desa Kuala Langsa Kecamatan Langsa Barat Kota Langsa. Letak Ekowisata Hutan Mangrove Kuala Langsa $\pm 8 \mathrm{Km}$ dari pusat Kota Langsa. Luas hutan mangrove yang ada di Desa Kuala Langsa saat ini memiliki hutan mangrove yang luas yakni \pm 8000 Ha. Terdapat banyak kegitan masyarakat di Kuala Langsa, dimana kegitan itu sangat berkaitan dengan ekosistem di wilayah pesisir seperti penangkapan ikan, udang, kepiting, kerang dan juga wisata pesisir. Penduduk di Kuala Langsa berjumlah 453 kepala keluarga, dimana manyoritas mata pencaharian masyarakatnya adalah nelayan serta juga ada jenis pekerjaan yang lain seperti PNS, TNI, tukang, montir, pedagang, montir dan wiraswsata.

Ekowisata hutan mangrove di Kuala Langsa merupakan kawasan hutan lindung telah dimanfaatkan sebagai salah satu kawasan wisata yang dikelola pemerintah dan masyarakat sekitar. Saat ini kawasan hutan mangrove Kuala Langsa sudah menjadi tujuan wisata andalan Kota Langsa, sebagai wisata edukasi mangrove yang berskala internasional. Hutan mangrove banyak memberikan manfaat kepada masyarakat Kuala Langsa tidak hanya menjadi tempat wisata, tetapi pohon mangrove sendiri menghasilkan buah yang dapat diolah menjadi sirup mangrove, selai mangrove serta aneka ragam kerajinan dari pohon mangrove.

Pemukiman masyarakat di Desa Kuala Langsa merupakan suatu pemukiman yang letaknya berjajar di sepanjang jalan arah menuju ke hutan mangrove. Ini merupakan salah satu pemandangan yang dapat dinikmati oleh pengunjung yang ingin berwisata ke hutan mangrove di Desa Kuala Langsa, 
sehingga aksebilitas untuk berwisata lebih mudah. Karena kondisi yang teerletak di pinggiran pantai, oleh karena itu rumah penduduk berbentuk rumah panggung dengan kondisi lantai yang disesuaikan dengan kondisi pasang surut air laut. Karena letak desa yang tidak berjauhan dari pusat kota, maka Desa Kuala Langsa tidak merupakan desa yang terpencil sehingga penduduk setempat mudah untuk berinteraksi dengan penduduk di desa lain dan juga sangat terbuka dengan penduduk yang ada di desa yang berdekatan dengan Desa Kuala Langsa.

Keberadaan ekowisata hutan mangrove akan memberikan dampak positif dan negatif terhadap masyarakat yang ada di sekitar hutan mangrove. Adanya perubahan pola pikir, dimana aktivitas dan keadaaan masyarakat yang biasanya mereka sibuk dengan kegiatan mereka masing-masing baik di rumah maupun di luar rumah, tetapi semenjak adanya pengembangan ekowisata hutan mangrove membuat masyarakat mampu memanfaatkan kesempatan dan mencari peluang yang lebih baik untuk memenuhi kebutuhan mereka sehari-hari.

Sebelum adanya pengembangan hutan mangrove yang dijadikan sebagai tempat wisata masyarakat sekitar menggunakan kayu mangrove secara sembarangan tanpa memperhatikan kelestarian lingkungan. Setelah adanya situs ekowisata hutan mangrove, masyarakat yang awalnya bekerja memotong kayu mangrove, sekarang sudah memiliki pekerjaan lain seperti menjadi tukang parkir, menjadi penjaga atau pengawas lingkungan mangrove, berjualan di seputaran jalan menuju ke Kuala Langsa maupun menawarkan jasa atau sewa sampan atau boat. Kesempatan ini memberikan peluang yang sangat besar bagi masyarakat untuk terus menambah pendapatan dengan melakukan kegiatan kegiatan yang bermanfaat bagi pengunjung atau wisatawan yang datang ke Hutan Mangrove.

Upaya pelestarian dan pengembangan hutan mangrove terus dilakukan oleh pemerintah, hal ini terbukti dengan adanya penambahan penanaman bibit magrove yang baru. Pengembangan tempat wisata berupa saran dan prasana serta infrastruktur yang mendukung wisata hutan mangrove juga terus dilakukan oleh pemerintah yang bekerjasama dengan masyarakat setempat seperti pembangunan toilet, tempat ibadah, himbauan pelestarian hutan, serta tempat pembuangan sampah agar wisatawan yang berkunjung ke hutan mangrove merasa aman, tenteram dan nyaman.

Pengembangan ekowisata juga dapat menimbulkan dampak negatif bagi lingkup masyarakat sekitarnya, seperti kemungkinan terjadinya tingkat kriminalitas dan konflik sosial antar warga asli dan pendatang, hal ini terjadi karena adanya perubahan nilai dalam masyarakat yang cepat secara tiba-tiba. Namun demikian, secara umum hasil wawanOcara dan observasi menunjukkan bahwa pengembangan ekowisata hutan mangrove di Desa Kuala Langsa tidak memberikan dampak negatif. Hal ini karena masyarakat setempat bersifat terbuka terhadap pola pembaharuan, ramah dan mau bekerjasama demi kemajuan daerahnya.

\section{SIMPULAN}

Berdasarkan penelitian yang telah dilakukan mengenai dampak eksternalitas ekowisata hutan mangrove terhadap lingkungan hidup di sekitarnya, dengan studi kasus pada area ekowisata hutan mangrove Kota Langsa, maka dapat dinyatakan beberapa simpulan.

Dampak eksternalitas yang dinilai paling berpengaruh dalam aktivitas ekowisata ini adalah menjadi daya dukung lingkungan. Dampak-dampak lainnya adalah membuka 
lapangan kerja baru, meningkatkan jumlah pendapatan, meningkatkan kesejahteraan, menyediakan fasilitas umum, meningkatkan PAD, dan lain-lain. Sedangkan dampak yang rendah adalah menyebabkan konflik sosial.

Keberadaan hutan mangrove sangat menunjang tingkat perkembangan sosial dan perekonomian masyarakat di sekitarnya. Potensi daya tarik ekowisata di kawasan mangrove Kuala Langsa tergolong dalam kategori tinggi, sehingga layak untuk dikembangkan menjadi objek daya tarik ekowisata. Dari hasil penelitian, terlihat bahwa pengembangan ekowisata hutan mangrove lebih berdampak positif bagi lingkungan di sekitarnya. Hal ini dapat dilihat dari sejumlah hasil olahan data lapangan yang dilakukan oleh peneliti.

Rekomendasi yang dimunculkan berdasarkan penelitian ini adalah perlu dilakukan pembentukan kerjasama antara pengelola ekowisata dan masyarakat dalam mencapai tujuan bersama demi upaya meningkatkan perekonomian serta melestarikan hutan mangrove yang lebih baik lagi, maupun membentuk suatu kelembagaan pariwisata. Rekomendasi utama lainnya adalah perlu adanya peran pemerintah dalam menjamin keselamatan dan keamanan bagi para pengunjung baik lokal maupun luar daerah.

\section{REFERENSI}

Andiny, P. \& Irwan, M. 2009. Analisis Dampak Eksternalitas Aktivitas Industri Karet terhadap Lingkungan Hidup di Sekitarnya. Jurnal Ekonomi Bisnis dan Koperasi. 11(1): hal. 27-41.

Abdulsyani. 1994. Sosiologi Skematika, Teori dan Terapan. Jakarta: Bumi Aksara.

Arikunto, S. 2006. Prosedur Penelitian Suatu Pendekatan Praktik. Jakarta: Rineka Cipta.
Badan Perencanaan Pembangunan Daerah Kota Langsa. 2019. Rencana Pengembangan Ekowisata Kota Langsa. Kota Langsa: BAPPEDA Kota Langsa.

Badan Pusat Statistik. 2018. Statistik Daerah Kota Langsa. Langsa: Badan Pusat Statistik Kota Langsa.

Dahuri R., Rais, J., Ginting, S.P. \& Sitepu, M.J. 2001. Pengelolaan Sumberdaya Wilayah Pesisir dan Laut Terpadu. Jakarta: PT. Pradya Paramita.

Damanik, J. \& Weber, H.F. 2006. Perencanaan Ekowisata: Dari Teori ke Aplikasi. Indonesia: Penerbit ANDI.

Dinas Pemuda, Olah Raga dan Pariwisata. 2019. Jumlah Kunjungan Wisatawan Nusantara dan Mancanegara ke Objek Wisata di Kota Langsa pada Tahun 2018. Kota Langsa: Disporapar Kota Langsa.

Fandeli, C. \& Mukhlison. 2000. Pengusahaan Ekowisata. Yogyakarta: Fakultas Kehutanan Universitas Gadjah Mada bekerjasama dengan unit KSDA Daerah Istimewa Yogyakarta dan PT. Pustaka Pelajar.

Kasmir \& Jakfar. 2012. Studi Kelayakan Bisnis. Jakarta: Kencana.

Kete, S.C.R. 2016. Pengelolaan Ekowisata Berbasis Goa: Wisata Alam Goa Pindul. Yogyakarta: DeePublish.

Pitana, I.G. \& Gayatri, P.G. 2005. Sosiologi Pariwisata. Yogyakarta: Penerbit Andi.

Riduwan. 2009. Skala Pengukuran Varia bel-Variabel Penelitian. Bandung: Alfabeta.

Scheyvens, R. 2000. Promoting Women's Empowerment through Involvement in Ecotourism: Experiences from the Third World. Journal of Sustainable Tourism, 8(3): 232-249.

Soekanto, S. 2001. Sosiologi: Suatu Pengantar. Jakarta: Rajawali Press.

Suparmoko, M. 2014. Ekonomi Sumber daya Alam dan Lingkungan. Yogyakarta: BPFE Yogyakarta. 
The International Ecotourism Society (TIES). 2000. Ecotourism Statistical Fact Sheet. Nort Bennington. USA.

Wibowo. 2007. Dampak Pengembangan Ekowisata Kawasan Wisata Gunung
Merapi Merbabu terhadap Perubahan Struktur Masyarakat. Surakarta: FISIP Universitas Sebelas Maret 